\title{
The Acquisition of the English Locative Alternation by Kuwaiti EFL Learners
}

\author{
Abdullah M. Alotaib \\ PAAET \& CBE, Kuwait \\ E-mails: alotaibi917@gmail.com \& otaiby2013@gmail.com
}

Received: 02-05-2015

Published: 01-01-2016
Accepted: 30-08-2015

doi:10.7575/aiac.ijalel.v.5n.1p.65
Advance Access Published: October 2015

URL: http://dx.doi.org/10.7575/aiac.ijalel.v.5n.1p.65

\begin{abstract}
This study attempts to test whether 100 advanced Kuwaiti EFL learners have acquired the English locative alternation. A Grammaticality Judgment Task (GJT) was used to examine whether the participants have the ability to make a distinction between verbs that alternate between the figure-object frame and the ground-object frame and those verbs that do not. The researcher selected the verbs on the basis of Pinker's (1989) classification of alternating vs. nonalternating English locative verbs. The results show that the participants' performance on the alternating verbs was better than that on the non-alternating ones. They also reveal that negative transfer of the argument structure of the verbs from the participants' first language into English contributed to their erroneous answers on the test. Additionally, it has been argued that positive transfer from L1 also played a major role in the participants' correct answers on the test. The study concludes with some recommendations for further research.
\end{abstract}

Keywords: locative alternation, argument structure, syntax, theta roles, second language acquisition, Kuwaiti EFL learners

\section{Introduction}

In order to propose a theory that can account for the mystery of why certain verbs subcategorize for certain arguments, Pinker (1989, p. 8) examined four lexico-syntactic alternations, namely, the dative, locative, causative and passive. His investigation of these alternations was driven by the fact that they have the same learnability problem which was discovered by none other than Baker (1979). This well-known learnability problem i.e. Baker's paradox was named after the scholar who was the first to bring it to light viz., Baker. Table 1 below shows these four alternations:

Table 1. Four types of lexico-syntactic alternations described by Pinker (1989)

\begin{tabular}{lll}
\hline Type of alternation & Alternating verb & Non-alternating verb \\
\hline Passive & $\begin{array}{l}\text { Bill ate the cake } \\
\text { The cake was eaten by Bill }\end{array}$ & $\begin{array}{l}\text { the locket belongs to Marry } \\
\text { *the locket is belonged by Mary }\end{array}$ \\
\hline Causative & $\begin{array}{l}\text { Jennifer } \text { opened the door } \\
\text { The door } \text { opened }\end{array}$ & $\begin{array}{l}\text { the baby laughed } \\
\text { *Monica laughed the baby }\end{array}$ \\
\hline Dative & $\begin{array}{l}\text { Fred gave a ring to Maggie } \\
\text { Fred gave Maggie a ring }\end{array}$ & $\begin{array}{l}\text { Peter donated fifty dollars to the poor } \\
\text { *Peter donated the poor fifty dollars }\end{array}$ \\
\hline Locative & $\begin{array}{l}\text { Sam sprayed paint } \text { onto the fence } \\
\text { Sam sprayed the fence with paint }\end{array}$ & $\begin{array}{l}\text { Mark pushed the truck } \text { onto the road } \\
\text { *Mark pushed the road with the truck }\end{array}$ \\
\hline
\end{tabular}

According to Coppock (2009, p. 1), Baker's paradox is based on three presuppositions. Firstly, patterns which are characterised by being productive exhibit patterns regarded as arbitrary. Secondly, the existence of productive generalisations is a fact. Thirdly, ungrammatical evidence of a certain sentence type is unavailable i.e. children are not exposed to negative evidence since adults do not produce grammatically incorrect sentences. In particular, the productivity of a certain pattern is determined by the infinite number of items realising this pattern (Coppock, 2009). For instance, the double-object structure makes an appearance in an infinite number of dative verbs e.g. Fred gave a ring to Maggie. Thus, it is argued that the productivity of a certain pattern is determined when a new word is utilised to realise such pattern. Nevertheless, productive patterns do exhibit arbitrary exceptions. For example, even though the verb donate, which is similar in meaning to the verb give, subcategorises for [NP PP] i.e. Peter donated fifty dollars to the poor, it is viewed as odd in an [NP NP] or double-object structure i.e. *Peter donated the poor fifty dollars. Put in a slightly different way, even if the output is totally logical, it may be observed that a number of verbs are qualified to be used in some syntactic constructions whereas other verbs are not (Pinker, 1989). Based on the above discussion, one 
may argue that examining the acquisition of these lexico-syntactic alternations whether by children or adult second language learners can bring to light interesting conclusions that can facilitate the comprehension of the processes by which these learners acquire a particular structure. Specifically, investigating whether ESL/EFL learners can distinguish between alternating and non-alternating verbs is an interesting area to examine. The acquisition of the English locative alternation by ESL/EFL learners in general and Arab EFL learners in particular has not been given due attention. Therefore, this study aims at examining whether 100 advanced Kuwaiti EFL learners have acquired the English locative alternation.

\section{Literature review}

\subsection{Overview}

Several researchers (e.g. Mazurkerwich, 1984; Choi \& Lakshmanan, 2002; Kirby, 2010; Alotaibi \& Alajmi, 2015) investigated certain types of the four alternations discussed in the previous section. For example, Joo (2003) investigated the acquisition of the locative alternation by Korean EFL learners, examining whether language-universal vs. language-specific factors affected the acquisition process. The study's main aim was to examine whether the participants' first language has an impact on the acquisition of the English locative alternation, especially since English and Korean verbs share the broad-range constraints i.e. the semantic meaning of the locative but differ in the narrowrange constraints. To this end, the researcher used a forced-choice sentence selection task and a forced-choice picturedescription task to elicit data from second language learners whose first language was Korean in order to compare it to the control group i.e. native speakers of English. It was argued by Joo (2003) that the participants had acquired the broad-range constraints, but they had not acquired the narrow-range constraints. The results also revealed that transfer from L1 was not detected in the participants' answers.

In another recent study, Alotaibi \& Alajmi (2015) examined the acquisition of the passive alternation by fifty advanced Kuwaiti EFL learners. Using a GJT, the researchers investigated the participants' ability to distinguish between verbs that alternate and those that do not. The findings show that positive transfer from Arabic which is the participants' first language influenced their correct answers on the GJT, particularly regarding the verbs that passivise. Moreover, the participants' unfamiliarity with certain verbs caused them to provide faulty answers on the test. The most noticeable problems encountered by the participants were caused by verbs that do not alternate to passive voice. Such problems were attributed to the fact that some participants overgeneralised the passivisation rule on the one hand, and to the overlap between non-causative and the passive on the other. Based on the participants' overall score, the two researchers concluded that they have not fully acquired the English passive construction.

Through reviewing the related literature, it has become evident that little attention has been paid to the acquisition of the four lexico-syntactic alternations by ESL/EFL learners. In fact, the focus so far has been on the ability of children to acquire such problematic constructions (e.g. Kirby, 2010). It is also noticeable that the acquisition of the English locative alternation by EFL learners, Arab in particular, has not been given due attention in comparison with other types of alternation. Therefore, this study aims at examining the acquisition of the English locative alternation by Kuwaiti EFL learners. Investigation of this construction may shed light on the difficulties facing EFL learners in the acquisition of problematic syntactic structures. In particular, the current study aims at supplying answers to the following questions:

1. To what extent have 100 advanced Kuwaiti EFL learners acquired the English locative alternation?

2. Do they encounter any problems with particular types of verbs? If so, why?

The next section provides a description of the English locative alternation.

\subsection{English locative alternation}

Pinker (1989, p. 49) defines locative alternation as one that denotes a transfer of a substance or set of objects i.e. the content, theme or locatum onto or into a container or surface i.e. the container, the goal or location. It is typically taken that the content-oriented or theme-object form is the base member of this pair of construction, such that the locative alternation changes it into another construction called the container-oriented or goal-object form which takes the preposition with (Pinker, 1989, p. 49). This relies on whether the content or the goal is compulsory or not. Note that semantically speaking, the two constructions are not synonyms. In particular, according to Rappaport and Levin (1985), taking the goal-object form as an example, the goal should be totally filled or covered by the theme. However, if this type of effect, which is denoted by the verb, is not applicable, the verb does not alternate as in:

1) a. Monica threw the chair into the kitchen

b. *Monica threw the kitchen with the chair

2) a. Dexter loaded flour into the truck

b. Dexter loaded the truck with flour

Simply put, the locative alternation takes a verb which means "to cause $\mathrm{X}$ to go into or onto $\mathrm{Y}$ " and changes it into a verb which means "to cause $\mathrm{Y}$ to change state by means of putting $\mathrm{X}$ into or onto it". Thus, the entity which is casually affected is mapped onto the surface object position (Pinker, 1989, p. 64). When the verb cannot specify how a container or surface is able to change state as a result of the addition of an entity into or onto it, the alternation does not apply. 
Taking the previous discussion into account, broad-range rules, which constrain the acquisition of the four types of alternations, for the locative alternation changes a predicate which means "X moves $\mathrm{Y}$ into/onto $\mathrm{Z}$ " as in example (2a) into a second predicate which means " $\mathrm{X}$ causes $\mathrm{Y}$ to change its state by means of moving $\mathrm{Z}$ to $\mathrm{Y}$ " as in example (2b) (Pinker, 1989, p. 64). It should be noted here that the holism effect plays an important role in this type of broad-range constraints that is, in example (2b), the truck is totally filled with flour. Conversely, in example (2a), the truck is not necessarily full. In fact, lack of holism effect explains why the sentence below is ungrammatical:

3) a. Mark pushed the truck onto the road b. *Mark pushed the road with the truck

As seen in example (3) above, not all verbs alternate between the preposition on/into/onto and the preposition with. This can be due to the fact that some verbs exhibit arbitrariness in selecting their argument structure. That is, these verbs choose which kind of argument can serve as their direct object. Examples of these verbs are illustrated below:

4) a. Peter poured milk into the cup

b. *Peter poured the cup with milk

5) a. *Peter filled milk into the cup

b. Peter filled the cup with milk

Unlike the verb load, the two verbs fill and pour do not alternate between the two prepositions into/onto and the preposition with. Along these lines, the locative verbs are typically divided into three structures (Pinker, 1989):

a. End state verbs, only appearing with the preposition with i.e. the ground-object frame e.g. fill.

b. Motion verbs, only appearing with the prepositions on/into/onto i.e. the figure-object frame e.g. pour.

c. Alternating verbs, changing between the prepositions on/into/onto and the preposition with e.g. load.

This may explain why Pinker (1989) argues that verbs are picky. This is because verbs with particular meanings only permit one type of argument structure, but not the other. Pinker (1989, p. 126-28) outlined the narrow-range rules related to the locative alternation so that, verbs that share one class also share particular semantic traits that result in the same behaviour they follow in selecting their arguments. A number of these rules pertaining to alternating verbs are illustrated below:

a. verbs that indicate applying a force to a mass, causing ballistic motion in a specified spatial distribution along a trajectory e.g. sprinkle, spray, splash, squirt, inject.

b. verbs indicating a mass of a shape, size or type which is defined by the intended use of a container... is put into a container which enables it to achieve its function e.g. load, stock.

c. verbs indicating vertical arrangement on a horizontal surface e.g. stack, pile, heap.

d. verbs indicating that a mass is forced into a container against the limits of its capacity e.g. cram, pack, jam, crowd, stuff.

e. verbs indicating that a simultaneous forceful contact and motion of a mass against a surface e.g. spread, streak, rub, smudge, plaster, smear, brush.

f. verbs causing a mass to move in a widespread or non-directed distribution e.g. sow, scatter.

The next section sheds light on the methodology.

\section{Methodology}

\subsection{The participants}

One hundred students at the Public Authority of Applied Education and Training (PAAET) and College of Basic Education (CBE) were involved in the current study. Their mean age was 23 years old. The first language of the participants is Kuwaiti Spoken Arabic (KSA). The selection of the participants was done randomly so that every student had the chance to be selected. Since only advanced students were included in the current study, they were selected on the basis of their results on the English Placement Test (EPT). In particular, only those whose results ranged between 70 -85 were involved in this study. Note also that the selected participants have studied English intensively for 12 years and completed two important English courses at the CBE viz., E 161 and E 261. Such courses are particularly important since they address several complex syntactic structures in English such as the locative alternation. This age group was selected because it is assumed that the participants at this stage would have acquired the English locative alternation (cf. Alotaibi \& Alajmi, 2015).

\subsection{The tool}

In order to test the extent to which the participants have acquired the English locative alternation, the researcher opted for a Grammaticality Judgment Task (GJT). This research tool was utilised by several other researchers (e.g. Mazurkerwich, 1984; Choi \& Lakshmanan, 2002; Alotaibi \& Alajmi, 2015) to examine other types of alternation e.g. the passive and the dative alternation. The GJT is considered a reliable tool to elicit data that may enable the researcher to determine whether the participants have acquired the English locative alternation. This kind of data can also shed light on the acquisition process of other syntactically complex structures in English. Simply, the participants were required to tick the sentences they deemed grammatical and cross the ones they deemed ungrammatical (see Appendix 
A). The researcher selected 11 verbs to be used in the GJT. Specifically, six verbs that alternate, six verbs that do not alternate and two distracters i.e. verbs that cannot be passivised used ungrammatically were chosen. These verbs are outlined below:

- 5 non-alternating verbs:

insert, put, dip, fill, dribble, push

- 5 alternating verbs:

load, pile, squirt, spread, plaster, stuff

- 2 verbs that cannot be passivised used ungrammatically as distracters:

resemble, sleep

In the test, the alternating verbs appeared in two sentences in both the figure-object frame and the ground-object frame. However, the non-alternating verbs appeared in one grammatical sentence and in another ungrammatical one so that the researcher will be able to check whether the participants are aware of the difference between alternating vs. nonalternating verbs. In total, the test consisted of 26 items (see Appendix A). Note that this study deals with one type of locative alternation. Other researchers may be interested in investigating the second type which deals with the depletion effect rather than the holism effect.

To check whether the tool used in this study is valid, four native speakers of British English were given the test. Their results confirmed that the test is reliable and valid. Regarding ethical issues, the participation in the study was completely voluntary; the participants were given the choice to participate. The researcher also informed them that their data will be confidential.

The next section provides a description of the results and discusses them.

\section{Results and discussion}

As discussed previously, the main aim of this study is to examine whether 100 advanced Kuwaiti EFL learners have acquired the English locative alternation. This can be tested by examining whether the participants are able to distinguish between alternating and non-alternating verbs.

In general, the results demonstrated that the participants are unable to distinguish between alternating and nonalternating verbs in English. Put differently, the total mean of the participants' answers (39\%) show that they have not acquired the English locative alternation. They did not only encounter problems with non-alternating verbs, but also with alternating ones. However, such problems were with different degrees. That is, a big number of the participants ticked sentences such as *Monica dipped honey with the bread and considered it grammatically correct. This may exhibit that the participants may lack the ability to make a distinction between alternating vs. non-alternating verbs. Table 2 below shows the number and percentage of correct answers with respect to the verbs that alternate.

Table 2. Number and percentage of correct answers on alternating verbs on the test

\begin{tabular}{lll}
\hline Verbs that alternate & No. of correct answers & $\%$ of correct answers \\
\hline Load & 60 & $60 \%$ \\
\hline Pile & 32 & $32 \%$ \\
\hline Squirt & 54 & $54 \%$ \\
\hline Plaster & 22 & $22 \%$ \\
\hline Stuff & 59 & $59 \%$ \\
\hline Spread & 52 & $52 \%$ \\
\hline Total mean & 47 & $47 \%$ \\
\hline
\end{tabular}

An examination of Table 2 shows that the participants encountered many problems with alternating verbs. The total mean of correct answers (47\%) was below the passing average 50\%. However, Table 2 also demonstrates that the participants scored higher on certain items compared to others. For instance, 60 participants out of 100 provided correct answers on the GJT on the verb load, whereas only 22 participants out of 100 provided correct answers on the verb plaster. These results could be attributed to the fact that verbs such as load (60\%), squirt (54\%), stuff (59\%) and spread $(52 \%)$ also alternate in KSA. Thus, the participants may have transferred the lexico-syntactic knowledge they have of their first language i.e. KSA into English. As a result, they were able to provide correct answers on the GJT. This type of transfer, in which learners transfer a structure from their first language into L2 in which such structure is correct, is referred to as positive transfer (Saville-Troike, 2012). Examples of this case can be seen below:

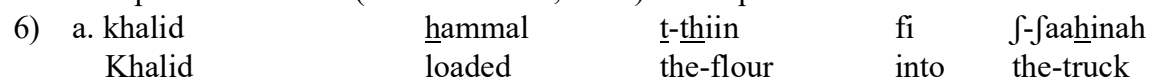

'Khalid loaded the flour into the truck'

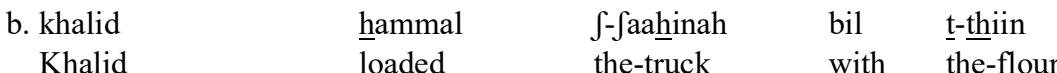

'Khalid loaded the truck with flour' 


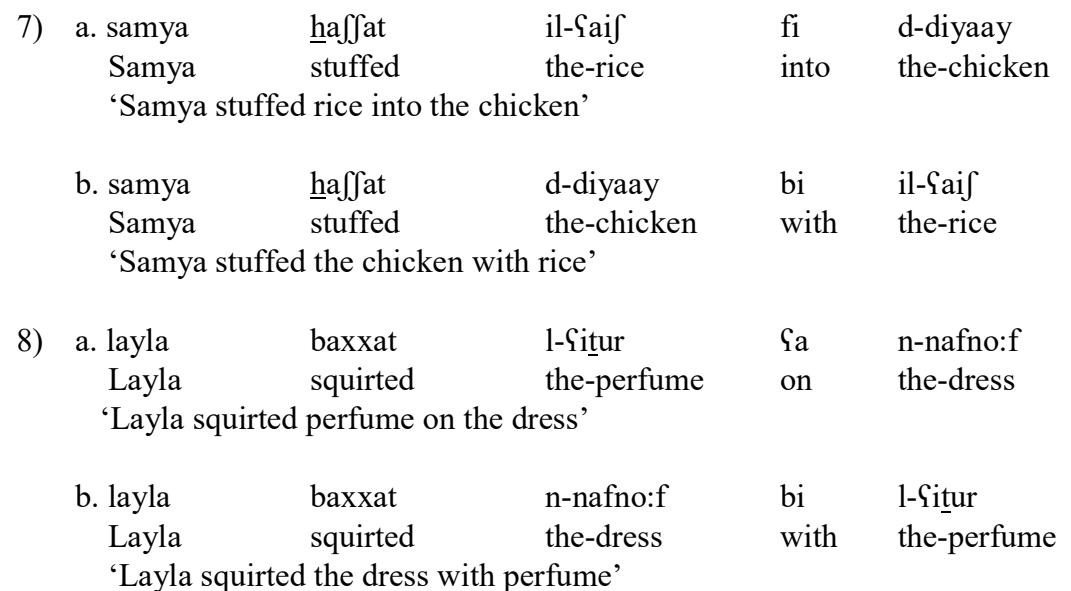

Examples (6-8) show that the same English locative verbs also alternate in KSA, which may have made it easier for the participants to supply correct answers on the test. On the contrary, examination of other studies shows that L1 does not always play a role in the participants' answers (cf. Joo, 2003). Note that similar examples were used on the GJT; they appeared as follows (see Appendix A):

13. Mark loaded the truck with flour

15. Mark loaded flour into the truck

23. Nancy stuffed the chicken with rice

7. Nancy stuffed rice into the chicken

1. Layla squirted perfume on the dress

9. Layla squirted the dress with perfume

Nevertheless, one may argue that positive transfer may not indicate that the participants have acquired a particular structure; they only transferred it from L1 to L2 in which this structure happens to be grammatical. In other words, the participants, probably, have not provided correct answers on the GJT as a result of their knowledge of the argument structure of the verbs in L2.

A study of Table 2 demonstrates that the participants encountered problems with other verbs on the test. For instance, only 32 and 22 participants out of 100 were able to provide correct answers on the verbs pile and plaster respectively. The reason behind such result could be that these two verbs are in fact non-alternating in KSA. The following examples illustrate this point:

\begin{tabular}{|c|c|c|c|c|c|}
\hline 9) & $\begin{array}{l}\text { a. ali } \\
\text { Ali }\end{array}$ & $\begin{array}{l}\text { kawwam } \\
\text { piled }\end{array}$ & $\begin{array}{l}\text { 1-kutub } \\
\text { the-books }\end{array}$ & $\begin{array}{l}\text { Sa } \\
\text { on }\end{array}$ & $\begin{array}{l}\text { 1-maktab } \\
\text { the-desk }\end{array}$ \\
\hline \multicolumn{6}{|c|}{ 'Ali piled the books on the desk' } \\
\hline & $\begin{array}{l}\text { b.*ali } \\
\quad \text { Ali } \\
\quad \text { (*`Ali p }\end{array}$ & $\begin{array}{l}\text { kawwam } \\
\text { piled } \\
\text { e desk wit }\end{array}$ & $\begin{array}{l}\text { 1-maktab } \\
\text { the-desk } \\
\text { ') }\end{array}$ & $\begin{array}{l}\text { bi } \\
\text { with }\end{array}$ & $\begin{array}{l}\text { 1-kutub } \\
\text { the-books }\end{array}$ \\
\hline 10) & $\begin{array}{l}\text { a. ahmad } \\
\text { Ahmad } \\
\text { 'Ahmad pl }\end{array}$ & $\begin{array}{l}\text { lazzag } \\
\text { plastered } \\
\text { d posters o }\end{array}$ & $\begin{array}{l}\underline{\mathrm{s}}-\underline{\mathrm{s} u w a r} \\
\text { the-posters } \\
\text { all' }\end{array}$ & $\begin{array}{l}\text { Ya } \\
\text { on }\end{array}$ & $\begin{array}{l}\text { t-to:fa } \\
\text { the-wall }\end{array}$ \\
\hline & b. *ahmad & lazzag & t-to:fa & bi & $\underline{\text { s-suwar }}$ \\
\hline & $\begin{array}{c}\text { Ahmad } \\
\text { (*`Ahmad }\end{array}$ & $\begin{array}{l}\text { plastered } \\
\text { ed the wal }\end{array}$ & $\begin{array}{l}\text { the-wall } \\
\text { osters') }\end{array}$ & with & the-posters \\
\hline
\end{tabular}

A look at examples (9-10) shows that the two verbs pile and plaster do not alternate in KSA. For example, the verb pile which alternates between the ground-object frame and the figure-object frame in English only takes the figure-object frame in KSA. Thus, the participants may have transferred their knowledge of the argument structure of these two verbs from KSA into English. However, this type of transfer is referred to as negative transfer since the structure is considered faulty in L2 (Saville-Troike, 2012). One may wonder why such discrepancy occurs; it can be argued that the semantic structure of these verbs is different in KSA compared to English; hence, they have different argument structures.

Moving on to the participants' answers on the verbs that do not alternate, Table 3 shows the number and percentage of correct answers on these verbs. 


\begin{tabular}{|c|c|c|}
\hline Verbs that alternate & No. of correct answers & $\%$ of correct answers \\
\hline Insert & 21 & $21 \%$ \\
\hline Put & 26 & $26 \%$ \\
\hline Dip & 27 & $27 \%$ \\
\hline Fill & 22 & $22 \%$ \\
\hline Dribble & 28 & $28 \%$ \\
\hline Push & 61 & $61 \%$ \\
\hline Total mean & 31 & $31 \%$ \\
\hline
\end{tabular}

Table 3 shows that the participants' scores on the verbs that do not alternate (31\%) are lower than those on the verbs that do (see Table 2). The lowest percentage of correct answers was on the verb insert (21\%), whereas the highest percentage was on the verb push (61\%). Starting with the low percentages, an examination of Table 3 demonstrates that the lowest percentage of correct answers were on the verbs insert (21\%), put (26\%), dip (27\%) and fill (22\%). These percentages could be accounted for by the fact that these verbs do alternate in KSA. The following examples illustrate this point:

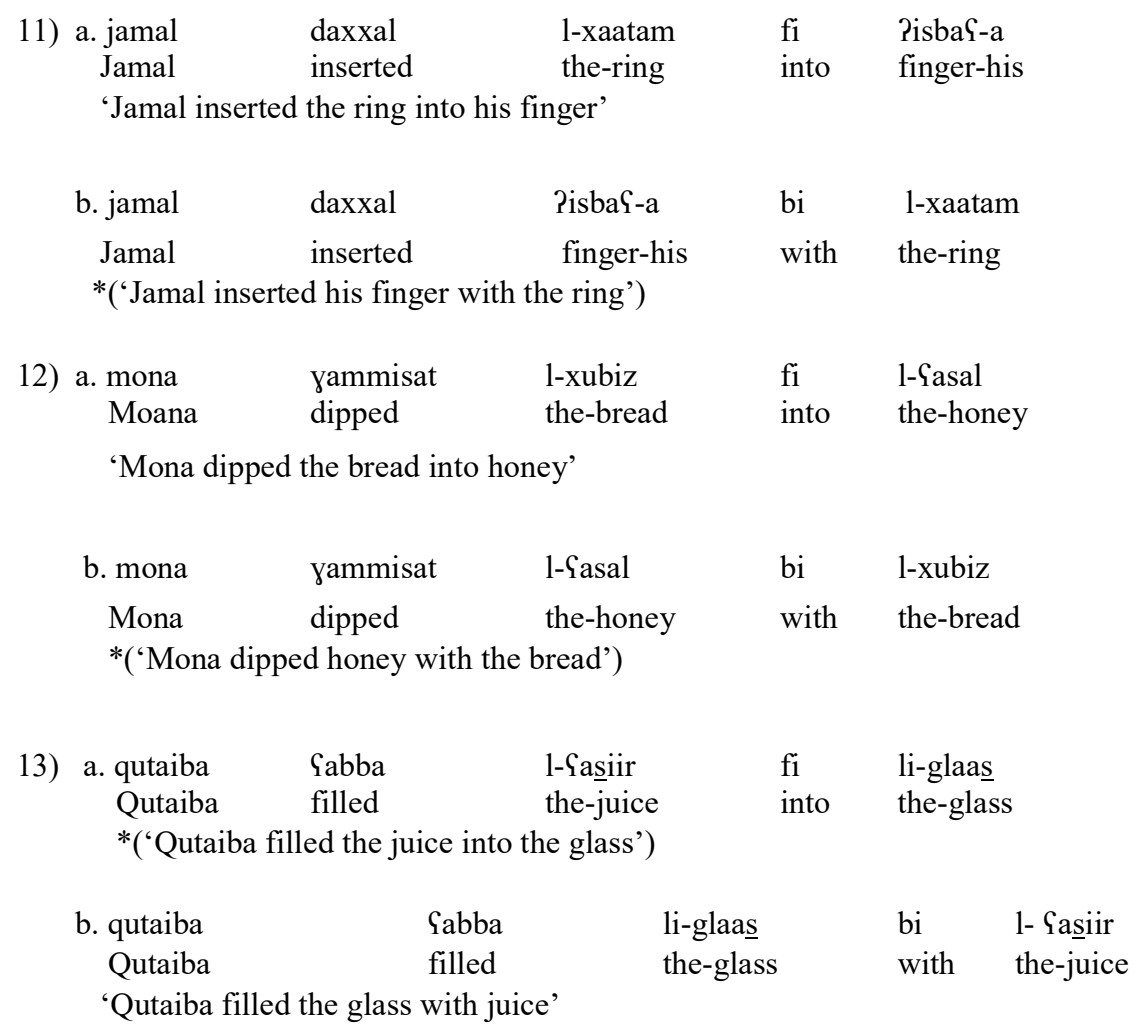

Examples (11-13) show that the verbs which are classified as non-alternating in English do actually alternate in KSA. For instance, the verb fill which only subcategorises for the ground-object frame in English takes the figure-object frame in KSA as well. In other words, it alternates. This discrepancy between English and KSA may have caused the participants to transfer their knowledge of their first language into English. Differently, the participants possibly thought that since these verbs alternate in KSA, then they may also do that in English. Hence, they provided erroneous answers on the GJT. Once again, it can be observed that negative transfer from L1 contributed to the participants' faulty answers on the test (cf. Choi and Lakshmanan 2002). Note that similar examples to the ones above were used on the test; they appeared as follows (see Appendix A):

6. Peter inserted the ring into his finger

16. *Peter inserted his finger with the ring

5. *He put the net with ball

12. He put the ball into the net

20. *Monica dipped honey with the bread

24. Monica dipped the bread into honey

2. *Bob filled juice into his glass

11. Bob filled his glass with juice

Note also that the percentage of correct answers on the verb dribble (28\%) was also low. This could be due to the fact that some participants' may not be familiar with this verb. 
On the other hand, it can be noticed that the percentage of correct answers on the verb push (61\%) was higher than that of the other verbs. This can be ascribed to the fact that this verb does not also alternate in KSA. Hence, positive transfer may have played a role in this example as in:
14) a. majid
dazz
$\int-\int a a h i n a h$
Sa
$\int-\int a a r i S$
Majid
pushed
the-truck
onto the-road

'Majid pushed the truck onto the road'

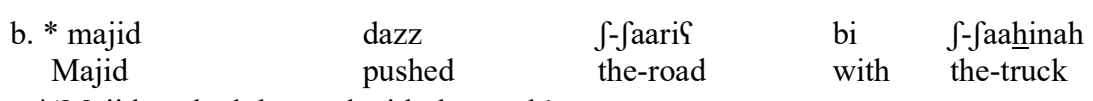

\section{Conclusion and recommendations}

This study investigated whether 100 advanced Kuwaiti EFL learners can distinguish between verbs that alternate between the figure-object frame and the ground-object frame and those that do not. To this end, the researcher utilised a Grammaticality Judgement task (GJT) to elicit the data. The results revealed that Kuwaiti EFL learners have not acquired the English locative alternation (total mean=39\%). This means that they encountered problems with both the broad-range constraints and the narrow-range constraints. Additionally, the results demonstrated that the participants' performance on the verbs that alternate $(47 \%)$ was better than that on the non-alternating verbs $(31 \%)$. The fact that some of the non-alternating verbs in English do alternate in KSA may have influenced the participants' answers on the test. Therefore, the researcher argued that negative transfer from L1 may have played a big role in the participants' faulty answers on the test. The participants also provided correct answers on both the alternating and non-alternating verbs. The researcher argued that this percentage of correct answers may be attributable to positive transfer from L1 to L2. Nonetheless, the researcher proposed that just because the participants transferred the argument structure of the verbs from L1 into L2, it does not mean that they have acquired them. This is because such knowledge of the argument structure of these verbs was not based on knowledge of L2, rather on knowledge of L1. Accordingly, it is recommended that EFL teachers may wish to focus more on the lexico-syntactic structures which cause a learnability problem (Pinker, 1989). Also, EFL learners need to be made aware of the differences between the alternating vs. non-alternating verbs. Teachers of English as a second/foreign language need to explain that sometimes subtle semantic differences between these verbs may give rise to a change in their argument structure. Finally, studies on the other type of locative alternation, which deals with the depletion effect, may shed light on the acquisition of these peculiar verbs.

\section{References}

Alotaibi, A. \& Alajmi. H. (2015). The acquisition of the passive alternation by Kuwaiti EFL learners International Journal of English Linguistics, 5, 44-52. http://dx.doi.org/10.5539/ijel.v5n1p44.

Baker, C. L. (1979). Syntactic theory and the projection problem. Linguistic Inquiry, 10, 533-81.

Choi, M.H. \& Lakshmanan, U. (2002). Holism and locative argument structure in Korean-English bilingual grammars. In Skarabela, B., Fish, S. \& Do, A. H.J (Eds), Proceedings of the $26^{\text {th }}$ annual Boston University conference on language development (pp. 95-106). Somerville, MA: Cascadilla Press.

Coppock, E. (2009). The logical and empirical foundations of Baker's paradox. PhD thesis. Stanford University, Stanford, California.

Joo, H.R. (2003). Second language learnability and the acquisition of the argument structure of English locative verbs by Korean speakers Second Language Research, 19 (4), 305-328. http://dx.doi.org/10.1191/0267658303sr225oa.

Kirby, S. (2010). Passives in first language acquisition: What causes the delay?. University of Pennsylvania Working Papers in Linguistics, 16, 109-117. http://repository.upenn.edu/pwpl/vol16/iss1/13.

Mazurkerwich, I. (1984). The acquisition of the dative alternation by second language learners and linguistic theory. Language Learning, 34, 91-108. http://dx.doi.org/10.1111/j.1467-1770.1984.tb00997.x.

Pinker, S. (1989). Learnability and cognition: The acquisition of argument structure. Cambridge: MIT Press.

Rappaport, M. and Levin, B. (1985). A case study in lexical analysis: The locative alternation. Unpublished manuscript, MIT Centre for Cognitive Sciences.

Saville-Troike, M. (2012). Introducing second language acquisition (2nd ed.). Cambridge: MIT Press. 
IJALEL 5(1):65-73, 2016

\section{Appendix A}

\section{Grammaticality Judgment Task (GJT)}

Read the following sentences. Put a tick $(\checkmark)$ next to any sentence you think grammatical and a cross $(X)$ next to any sentence you think ungrammatical. Your first decision is the one we want. Please do not change your answers.

\begin{tabular}{|c|c|c|}
\hline 1. & Layla squirted perfume on the dress & $\checkmark$ \\
\hline 2. & Bob filled juice into his glass & $x$ \\
\hline 3. & Jack spread butter on the bread & $\checkmark$ \\
\hline 4. & Jennifer plastered the wall with posters & $\checkmark$ \\
\hline 5. & He put the net with ball & $x$ \\
\hline 6. & Peter inserted the ring into his finger & $\checkmark$ \\
\hline 7. & Nancy stuffed rice into the chicken & $\checkmark$ \\
\hline 8. & Mark pushed the truck onto the road & $\checkmark$ \\
\hline 9. & Layla squirted the dress with perfume & $\checkmark$ \\
\hline 10. & Mark pushed the road with the truck & $x$ \\
\hline 11. & Bob filled his glass with juice & $\checkmark$ \\
\hline 12. & He put the ball into the net & $\checkmark$ \\
\hline 13. & Mark loaded the truck with flour & $\checkmark$ \\
\hline 14. & The baby dribbled the counter with milk & $x$ \\
\hline 15. & Mark loaded flour into the truck & $\checkmark$ \\
\hline 16. & Peter inserted his finger with the ring & $x$ \\
\hline 17. & Sam piled books on the desk & $\checkmark$ \\
\hline 18. & The baby dribbled milk on the counter & $\checkmark$ \\
\hline 19. & Jennifer plastered posters on the wall & $\checkmark$ \\
\hline 20. & Monica dipped honey with the bread & $x$ \\
\hline 21. & Jack spread the bread with butter & $\checkmark$ \\
\hline 22. & Sarah is resembled by her mother & $x$ \\
\hline 23. & Nancy stuffed the chicken with rice & $\checkmark$ \\
\hline 24. & Monica dipped the bread into honey & $\checkmark$ \\
\hline 25. & Sam piled the desk with books & $\checkmark$ \\
\hline 26. & The boy was slept by the nanny & $x$ \\
\hline
\end{tabular}

\section{Appendix B}

Arabic sounds

\begin{tabular}{|c|c|c|}
\hline Arabic consonants/vowels & Symbols & Description \\
\hline 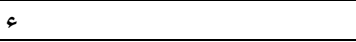 & ? & voiceless glottal stop \\
\hline ب & $\mathrm{b}$ & voiced bilabial stop \\
\hline$ت$ & $\mathrm{t}$ & voiceless dento-alveolar stop \\
\hline$\dot{\Xi}$ & $\theta$ & voiceless inter-dental fricative \\
\hline ج & $\mathrm{j}$ & voiced post-alveolar affricate \\
\hline$\tau$ & $\underline{\mathrm{h}}$ & voiceless pharyngeal fricative \\
\hline$\dot{\tau}$ & $\mathrm{x}$ & voiceless uvular fricative \\
\hline 2 & $\mathrm{~d}$ & voiced dento-alveolar stop \\
\hline ذ & д & voiced alveolar fricative \\
\hline $\mathrm{J}$ & $\mathrm{r}$ & voiced alveo-palatal trill \\
\hline j & $\mathrm{z}$ & voiced alveolar fricative \\
\hline س & $\mathrm{s}$ & voiceless alveolar fricative \\
\hline ش ش & s & voiceless alveo-palatal fricative \\
\hline ص & $\underline{\mathrm{s}}$ & voiceless alveolar emphatic fricative \\
\hline ض ض & $\underline{\mathrm{d}}$ & voiced alveolar emphatic stop \\
\hline b & $\underline{t}$ & voiceless dento-alveolar emphatic stop \\
\hline
\end{tabular}




\begin{tabular}{|c|c|c|}
\hline b & $\underline{\underline{\partial}}$ & voiced alveolar emphatic fricative \\
\hline$\varepsilon$ & S & voiced pharyngeal fricative \\
\hline$\dot{\varepsilon}$ & $\gamma$ & voiced uvular fricative \\
\hline ف & $\mathrm{f}$ & voiceless labio-dental fricative \\
\hline ق & $\mathrm{q} / \mathrm{g}^{\mathrm{i}}$ & voiceless/voiced uvular stop \\
\hline S & $\mathrm{k}$ & voiceless velar stop \\
\hline J & 1 & voiced alveolar lateral \\
\hline 5 & $\mathrm{~m}$ & voiced bilabial nasal \\
\hline ن & $\mathrm{n}$ & voiced alveolar nasal \\
\hline$\circ$ & $\mathrm{h}$ & voiceless glottal fricative \\
\hline 9 & $\mathrm{~W}$ & voiced labio-velar glide \\
\hline ي & $\mathrm{y}$ & voiced palatal glide \\
\hline$\Gamma$ & $\mathrm{a}$ & low short central unrounded \\
\hline$l^{3} \mid$ & $\mathrm{u}$ & high short back rounded \\
\hline 1.1 & $\mathrm{i}$ & high short front unrounded \\
\hline i & aa & low long central unrounded \\
\hline وو & $\mathrm{uu}$ & high long back rounded \\
\hline يبي & ii & high long front unrounded \\
\hline 9 & o: & mid long back rounded \\
\hline او & aw & low short front unrounded + labio-velar glide \\
\hline اي & ay & low short front unrounded + palatal glide \\
\hline يبي & ee & mid long front unrounded \\
\hline
\end{tabular}

Note

i These symbols represent the voiceless and voiced uvular stop. 